\title{
AREÚSA AND THE NEIGHBORS
}

\author{
David Hook \\ King's College London
}

Recent studies of medieval prostitution and its regulation have confirmed the importance of a knowledge of the contemporary legal and administrative context in understanding not only the general situation presented in Celestina, but also specific textual details. The connection between this context and textual points such as Celestina's caution on approaching Areúsa's house with Pármeno in Act VII ("entremos quedo; no nos sientan sus vezinas" [p. 370]),' and Areúsa's fear, ostensibly that the neighbours will tell her absent lover if she betrays him with Pármeno ("tengo vezinas embidiosas; luego lo dirán" [p. 375]), but possibly also of denunciation to the authorities, has been pointed out in separate articles by María Eugenia Lacarra and Alan Deyermond. ${ }^{2}$ As publication and study of the fifteenth- and sixteenth-century municipal records of Spanish communities progresses, further cases of regulation of the trade in sexual services will continue to emerge which may cast further light on such aspects of Celestina. For example, to the instances of municipal control of prostitution already noted by Lacarra may be added that of Zamora, where a payment due to the council in 1500 implies

'Quotations are from the edition by Peter E. Russell, Comedia o Tragicomedia de Calisto y Melibea, Clásicos Castalia, 191, Madrid: Castalia, 1991.

${ }^{2}$ Lacarra, "El fenómeno de la prostitución y sus conexiones con La Celestina," in Historias y ficciones: Coloquio sobre la literatura del siglo XV, ed. R. Beltrán, J. L. Canet, \& J. L. Sirera (Valencia: Universitat de València, Departament de Filologia Espanyola, 1992), pp. 267-278, at 275; id., "La evolución de la prostitución en la Castilla del siglo XV y la mancebía de Salamanca en tiempos de Fernando de Rojas," in Fernando de Rojas and 'Celestina': Approachingthe Fifth Centenary, ed. I. A. Corfis and J. T. Snow (Madison: Hispanic Seminary of Medieval Studies, 1993), pp. 33-78; Deyermond, "Female societies in Celestina," in Fernando de Rojas and 'Celestina': Approachingthe Fifth Centenary, pp. 1-31, at 12. 
a recent move to relocate the local prostitutes; it is not, however, clear from the document whether the proposed residence had actually materialised: ${ }^{3}$

De Risudo, vesino del Arraval de la Feria desta dicha çibdad, mill mrs. de fuero de un suelo que la çibdad le aforó para faser en él aposentamiento para las mugeres de mançebía, a pagar por el dicho día.

Another aspect of the problem is illustrated by an entry in the unpublished actascapitulares of the council of Ayamonte, Huelva, for Tuesday 4 April 1571 (Archivo Municipal de Ayamonte, legajo I, f. 74v): ${ }^{4}$

Sobre mugeres de amores.

este dia se dio petiçion por juan martyn moriel y otros vezinos diziendo que las mugeres que estan en las casas de gonçalo martin son de amores y traen perjuyzio morar alli probeyose que se vayan a salir a otra parte dentro en treinta dia[s] so çierta pena.

Fourteen years later, at its meeting on Friday 24 May 1585 (AMA, legajo II, ff. $18 \mathrm{v}-19 \mathrm{r}$ ), the council returned to the same topic:

En este cabildo se trato y confirio sobre que las mugeres publicas no esten en la parte y lugar donde de prezente estan y por yvitar muchos ynconvinientes y desensias que suele aver en cazos semejantes por que es pasaje de la mas parte del lugar y prosesiones y el santisimo sacramento se acuerda que para que se busque parte y lugar mas comoda para onde esten se deputa que lo vean y den orden a buscarles el sitio y casas $/ 19 \mathrm{r} /$ onde vivan las dichas mujeres a los señores francisco uaselo y juan de savalla.

\footnotetext{
${ }^{3}$ Manuel Fernando Ladero Quesada, La ciudad de Zamora en la épocade los Reyes Católicos. Economia y gobierno(Zamora: Instituto de Estudios Zamoranos 'Florián de Ocampo', \& Diputación de Zamora, 1991), p. 351. The entry is in the "Fueros cobrados por el concejo de Zamora, Año 1500" (Archivo Municipal de Zamora, Legajo 17 , documento 16 ).

${ }^{4}$ My transcription, with contractions resolved in italics. I am grateful to the Excmo. Ayuntamiento de Ayamonte for permission to consult the early records in the Archivo Municipal, and to the staff of the Archivo for their kind assistance. My research there was supported by a grant from the the Research Fund of the School of Humanities of King's College London, for which I record my appreciation.
} 
Complaints from residents, then as now, were an important source of action by municipal authorities to control prostitution. This may also explain Celestina's remark about being reassured by the fact that Areúsa's neighbours are talking to her ('hasta tus vezinas me parescen bien y se me alegra el coraçón cada vez que las veo, porque sé que hablan contigo', p. 375): since Areúsa is evidently still found socially acceptable, her activities cannot yet have been discovered. The question naturally arises from this of how long Areúsa has been resident at her present independent establishment; may Celestina not be the only character in the text to have moved house recently? Despite their ostensible concern with the status of domestic servants, one wonders whether the strongly emphatic nature of Areúsa's assertions in Act IX concerning her independence, and her apparent need to seek Celestina's approval for this ('Por esto, madre, he quesido más vivir en mi pequeña casa', Russell, pp. 416-17, followed by Celestina's reassuring reply 'En tu seso has estado. Bien sabes lo que hazes', p. 417), may be relevant to this question. A similar consideration may arise from the fact that, in the Tragicomedia,Sosia has to inform Tristán of the identity of the resident of the house which Elicia is entering when he sees her going to visit Areúsa (indicating, incidentally, that the latter's dwelling must therefore be visible from Calisto's house: Act XIV, p. 516).

Another aspect of prostitution encountered in Celestina, and noted in recent studies, is the question of the succession in, or transmission of, this activity. ${ }^{5}$ A municipal ordinance, passed on 6 March 1499 by the council at Valladolid, attempts to control the recruitment of women into prostitution by forbidding their residing with known prostitutes: ${ }^{6}$

Que ninguna ramera nin muger enamorada tenga moça nin muger, nin bivan con ellos.

Otrosy ordenaron que ninguna ramera ni muger enamorada, públicamente sea osada de tener mugeres e moças, so pena de çient açotes e que ninguna moça nin muger, de fasta quarenta annos, sea osada de bivir con las dichas rameras e mugeres enamoradas, so la dicha pena.

${ }^{5}$ Lacarra, "La evolución," p. 46; Deyermond, pp. 17-18.

${ }^{6}$ Libro de Actas del Ayuntamiento de Valladolid, Año 1499, transcribed by Fernando Pino Rebolledo, Publicaciones del Archivo Municipal de Valladolid (Valladolid: Ayuntamiento, 1993), p. 69, no. 146. 
One is reminded of the youthful residents of Celestina's house when her activity was at its height, as described both by Pármeno in Act I ('muchas moças, destas sirvientes, entravan en su casa', Russell p. 242) and Celestina herself in Act IX ('nueve moças de tus días, que la mayor no passava de deziocho años y ninguna havia menor de catorze', 417). The Valladolid ordinance, contemporary with the first known edition of the Comedia, may indicate, in its reference to the age after which women's residence was not to be controlled, that an important point is being made in the allusion by Celestina to the age of the moças in her former establishment quite apart from that of its obvious significance in sexual terms.

Further documentary evidence may well assist in clarifying these and other points; a problem with later sixteenth-century material is, of course, in assessing how far it is relevant to the circumstances pertaining towards the end of the previous century.

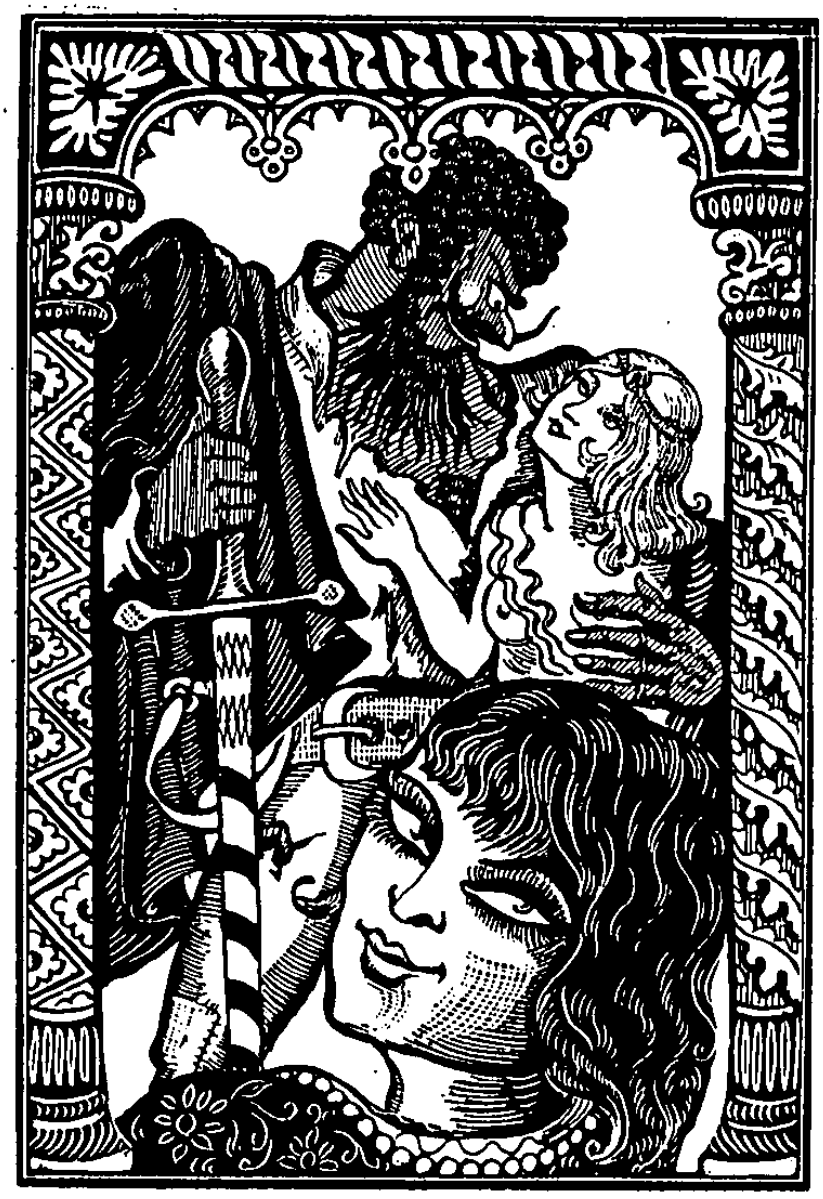

Centurion, Areúsa, Elicia. Maurice L'Hoir (1943). 